\title{
Lokakarya Literasi Digital Sebagai Upaya Pemilahan Berita Hoaks Di Desa Menjing, Kecamatan Jenawi, Kabupaten Karanganyar
}

\author{
Markhamah', Atiqa Sabardila², Tri Santoso $^{3}$, Wipit Sapitri ${ }^{4}$, Safrudin \\ Athfalusholeh ${ }^{5}$ \\ Magister Pengkajian Bahasa, Universitas Muhammadiyah Surakarta \\ Email:1mar274@ums.ac.id, 2as193@ums.ac.id,3ts674@ums.ac.id, \\ ${ }^{4}$ wipitsapitri03@gmail.com, 5nextatfal@gmail.com
}

\begin{abstract}
News hoaks rife produced and spread on social media among young people. The news can trigger disputes and threaten social disintegration. The existence of this phenomenon is due to inaccurate people sorting out news that is shared on social media. Based on the above phenomenon community service aims (1) to socialize news sorting strategies: hoaks, (2) to socialize politeness in spreading news on social media, and (3) to train young people in writing news on social media. These community service activities are carried out in Menjing Village, Jenawi District, Karanganyar Regency. Participants in this community service are members of Karangtaruna Menjing Village, Jenawi District, Karanganyar Regency. The strategy in community service is through workshops and hands-on practice.
\end{abstract}

Keywords: Hoaks, Social media, Digital literacy

\section{Pendahuluan}

Teknologi yang semakin berkembang memudahkan manusia untuk berkomunikasi satu sama lain. Komunikasi yang terjalin sudah tak lagi mengenal jarak dan waktu. Mereka menghubungkan diri dengan alat komunikasi digital. Alat komunikasi digital yang digunakan manusia berupa smartphone, gawai ataupun semacamnya. Dengan alat itu manusia dapat dengan cepat memberikan kabar dan juga menerima kabar. Kabar-kabar tersebut dapat dibagikan melalui media sosial baik WhatApps, facebook, twitter, instagram, dan portal berita daring. Kebebasan akses yang diberikan kepada setiap manusia melalui beberapa media sosial di atas memacu 
dengan mudahnya berita hoaksdiproduksi dan dibagikan ke khalayak. ${ }^{1}$ Kebanyakan masyarakat sudah tidak lagi menggunakan akal sehatnya ketika mendapatkan berita atau jarkoman melalui media sosial. Berita yang mereka anggap cocok dengan dirinya mereka bagikan ke beberapa teman dan grupgrup tertentu. Padahal belum tentu berita tersebut benar. Celah-celah yang seperti ini dimanfaatkan oleh para penerbar kebencian yang memanfaatkan berita hoaks untuk memobilisir dukungan atas kebijakan atau isu tertentu. Tentunya ini berhaya jika berita hoaks terus-terusan dikonsumsi dan disebar oleh masyarakat tanpa mengetahui atau menyelidiki kebenaran berita terlebih dahulu.

Fenomena di atas sangat berbahaya yang dapat menimbulkan adanya bencana post truth. Post truth merupakan fenomena sosial yang ada saat ini ${ }^{2}$ Mereka yang terdampak dan terimbas post truth akan mempercayai kebenaran hanya dari versi mereka sendiri meskipun berita tersebut hoaks dan tidak terbukti kebenarannya. ${ }^{3}$ Mereka tidak mau mempercayai kebenaran yang bukan berasal dari dirinya atau kelompoknya. Dengan bahasa sederhana mereka hanya ingin tahu yang mereka ingin ketahui. Efek bahaya dari post truth dapat menimbulkan perpecahan yang membawa ke arah disintegrasi bangsa. Bangsa Indonesia yang dibangun atas dasar keanekaragaman yang saling menghargai dan toleransi dapat dirusak dengan adanya berita hoaks.

Survei Alvara Institute (2017) menunjukkan bahwa mulai tahun ini bangsa Indonesia dianugerahi bonus demografi. Dengan adanya bonus demografi ini mayoritas penduduk Indonesia ialah para remaja yang berusia 17 tahun ke atas. Para remaja ialah yang memegang peranan penting saat ini.

1 Tania, L., Marindra, G., Melissa, M., Alviyani, V., Risty, I., \& Risalina, R. Anti Hoax Campaign: Research Based. Manasa, 6(2), 120, 2018.

2 Hancock, J. T. Digital Deception. Oxford Handbook Of Internet Psychology, 289, 2007.

${ }^{3}$ Keyes, R. The Post-Truth Era: Dishonesty And Deception In Contemporary life. Macmillan, 13,2004 
Mereka berkomunikasi, berjualan, hingga menyebarkan berita melalui media sosial. Tentu dengan adanya fenomena ini para remaja harus dibekali dengan adanya literasi digital. Hal ini dilakukan dengan tujuan untuk mencegah maraknya berita bohong yang meresahkan dan juga mengancam disintegrasi bangsa. Selain itu, juga bertujuan untuk mengajarkan para generasi muda memilah mana berita yang hoaks dan mana berita yang didasarkan pada fakta dan data yang benar.

\section{Metode}

1. Permasalah Mitra

Masalah yang ada di kalangan remaja Desa Menjing, Kecamatan Jenawi, Kabupaten Karanganyar ialah belum optimalnya mereka menggunakan media sosial untuk berkabarkan dan menyebarkan berita yang baik kepada masyarakat. Permasalah di atas dipicu karena faktor mereka belum dapat mimilah mana berita yang benar dan berita yang hoaks. Permasalah tersebut perlu untuk diselesaikan dan ditangani untuk mencegah maraknya fenomena post truth yang mengancam distintegrasi bangsa.

2. Pemecahan Masalah

Permasalahan yang ada di Desa Menjing, Kecamatan Jenawi, Kabupaten Karanganyar dapat diatasi dengan menyelenggarakan lokakarya (workshop) literasi digital kepada pemuda desa. Lokakarya yang diadakan berupa pelatihan mengidentifikasi berita hoaks danpelatihan menulis berita berbdasarkan fakta yang ada di lapangan. Adapun materi disampaikan dalam kegiatan pengabdian masyarakat ini berupa (a) materi strategi pemilahan berita hoaks, (b) materi kesantunan dalam menyebarkan berita di media sosial, dan (c) materi penulisan berita di media sosial. 
3. Pelaksanaan dan Keberlanjutan

Pelaksanaan lokakarya literasi digital sebagai upaya pemilahan berita hoaks di Desa Menjing, Kecamatan Jenawi, Kabupaten Karanganyar berlangsung pada Sabtu, 24 November 2018, pukul 19.00-21.00 WIB. Kegiatan bertempat di rumah pimpinan karang taruna di tempat tersebut. Adapun peserta pada kegiatan tersebut sejumlah 30 peser tayang berasal dari perwakilan pemuda dari berbagai Rukun Tetangga (RT) di wilayah tersebut.

Ada berbagai rangkaian acara pada saat pelaksanaan pengabdian kepada masyarkat. Di bawah ini disajikan susunan acara yang dimaksud.

Tabel 1. Susunan Acara Pengabdian Masyarakat

\begin{tabular}{|c|c|c|}
\hline Waktu & Acara & Pj. \\
\hline \multirow{4}{*}{$18.30-19.00$} & Pembukaan & Bagas Anjamoro \\
\hline & 1. Menyanyikan Lagu Indonesia Raya & Mira Indriani \\
\hline & 2. Pembacaan Teks Pancasila & Ni'mah Afifah \\
\hline & 3. Sambutan Ketua Karangtaruna & Rivano Muhammad \\
\hline \multirow{4}{*}{$19.00-20.30$} & $\begin{array}{l}\text { Acara Inti Pengabdian kepada } \\
\text { Masyarakat }\end{array}$ & \multirow{6}{*}{$\begin{array}{l}\text { Prof. Markhmah, } \\
\text { Dr. Atiqa Sabardila, } \\
\text { Tri Santoso, Wipit } \\
\text { Sapitri, Safrudin } \\
\text { Athfalusholeh }\end{array}$} \\
\hline & Strategi Pemilahan Berita Hoaks & \\
\hline & Menulis Kreatif di Media Sosial & \\
\hline & Santun Bermedia Sosial & \\
\hline $20.30-21.00$ & Tanya Jawab & \\
\hline $21.00-21.20$ & Evaluasi dan Tindak Lanjut & \\
\hline $21.20-21.30$ & Penutupan & Bagas Anjamoro \\
\hline
\end{tabular}

Sumber: Dokumentasi, 2018

Acara dimulai dengan pembukaan dengan menyanyikan lagu Indonesia Raya, pembacaan teks Pancasila, dan sambutan ketua karangtaruna.

Lokakarya Literasi Digital Sebagai Upaya Pemilahan Berita Hoaks Di Desa Menjing, 
Selanjutnya, acara inti yaitu pengabdian kepada masyarakat. Adapun materi yang disampaikan dalam kegiatan lokakarya ini terdiri dari tiga materi. Pertama,strategi pemilahan berita hoaks di media sosial. Materi yang disampaikan diawali dengan memahamkan peserta mengenai media sosial dari batasan, ciri-ciri, dan bentuk-bentuk media sosial. Selanjutnya disampaikan materi mengenai berita hoaks dan berbagai karakteristiknya. Berita hoaks merupakan berita bohong yang dapat memecah belah bangsa untuk itu sangat ditekankan pada penyampaian materi ini.

Materi kedua yang disampaikan ialah santun bermedia sosial. Materi ini di awali dengan penyampaian kondisi media sosial saat ini. Kemudian diakhiri dengan materi upaya menciptakan sopan santun di media sosial.

Ketiga, materi mengenai menulis kreatif di media sosial. Pada materi ini dipaparkan mengenai tata cara menulis konten di media sosial yang bermanfaat, menarik, dan tidak hoaks. Pemateri juga menyampaikan contohcontoh caption di media sosial yang termasuk berita hoaks. Tak hanya itu, turut ditampilan caption media sosial yang menarik. Materi-materi tersebut disampaikan oleh Prof. Markhmah, Dr. Atiqa Sabardila, Tri Santoso, Wipit Sapitri, Safrudin Athfalusholeh.

Sebelum acara diakhiri dilakukan pengisian kuesioner sebagai bahan evaluasi kegiatan. Dari hasi evaluasi yang ada disimpulkan bahwa kegiatan tersebut berjalan dengan lancar. Mereka dapat menerima informasi atau materi yang disampaikan pembicara, dan 100\% mengharapkan acara semacam ini dapat diselenggarakan lagi. Keberlanjutan dari kegiatan ini sangat diharapkan. Selain untuk memberikan informasi dan pengetahuan baru ke pemuda setempat juga melatih pemuda setempat untuk melatih menulis di media sosial. Hal ini menjadi penting karena saat ini banyak ditemukan para pelanggar UU ITE yang kebanyakan mereka dijerat karena tidak santun saat bertutur kata di media sosial. 


\section{Hasil dan Diskusi}

Perkembangan informasi digital masyarakat tidak lagi menggunakan akal sehatnya ketika bermedia sosial. Apalagi ketika mendapatkan berita atau jarkoman melalui media sosial. Berita yang mereka anggap cocok dengan dirinya mereka bagikan ke beberapa teman dan grup-grup tertentu. Padahal belum tentu berita tersebut benar. Celah-celah yang seperti ini dimanfaatkan oleh para penerbar kebencian yang memanfaatkan berita hoaks untuk memobilisir dukungan atas kebijakan atau isu tertentu. Tentunya ini berhaya jika berita hoaks terus-terusan dikonsumsi dan disebar oleh masyarakat tanpa mengetahui atau menyelidiki kebenaran berita terlebih dahulu.

Fenomena di atas sangat berbahaya yang dapat menimbulkan adanya bencana post truth. Post truth merupakan fenomena sosial yang ada saat ini. ${ }^{4}$ Mereka yang terdampak dan terimbas post truth akan mempercayai kebenaran hanya dari versi mereka sendiri meskipun berita tersebut hoaks dan tidak terbukti kebenarannya. ${ }^{5}$ Mereka tidak mau mempercayai kebenaran yang bukan berasal dari dirinya atau kelompoknya. Dengan bahasa sederhana mereka hanya ingin tahu yang mereka ingin ketahui. Efek bahaya dari post truth dapat menimbulkan perpecahan yang membawa ke arah disintegrasi bangsa. Bangsa Indonesia yang dibangun atas dasar keanekaragaman yang saling menghargai dan toleransi dapat dirusak dengan adanya berita hoaks. Kegiatan pengabdian kepada masyarakat ini dilakukan atas kerjasama Magister Pengkajian Bahasa, Universitas Muhammadiyah Surakarta dengan karang taruna Desa Menjing, Kecamatan Jenawi, Kabupaten Karanganyar. Acara dilaksanakan di aula kantor kepala Desa Jenawi. Di bawah ini merupkan rincian kegiatan yang telah dilakukan. 2007.

${ }^{4}$ Hancock, J. T. Digital Deception. Oxford Handbook Of Internet Psychology, hal.289,

${ }^{5}$ Keyes, R. The Post-Truth Era: Dishonesty And Deception In Contemporary life. Macmillan, Hal. 13, 2004. 


\section{Tahap Pertama: Sosialisasi Strategi Pemilahan Berita Hoaks}

Kegiatan pengabdian kepada masyarakat ini dilakukan pada tanggal 13 November 2018 bertempat di aula kantor kepala Desa Jenawi. Adapaun peserta kegiatan ini sejumlah 30 orang yang terdiri dari pemuda di desa tersebut. Narasumber yang memberikan materi sosialisasi strategi pemilahan berita hoaksialah Prof. Dr. Markhmah, M.Hum dan Dr. Atiqa Sabardila, M.Hum.

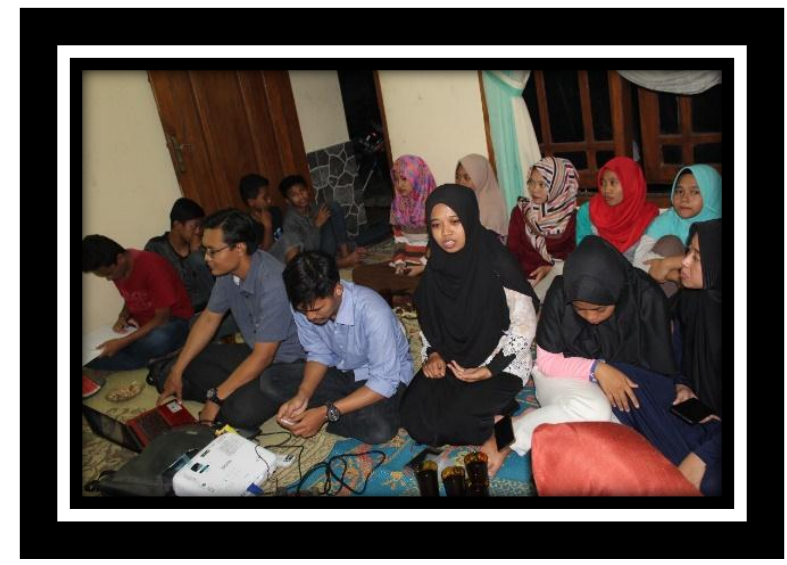

Gambar 1. Narasumber Menyampaikan Materi Strategi Pemilahan Berita Hoaks

Hoaks merupakan istilah dalam dunia ilmu komunikasi. Istilah ini merupakan kata yang berasal dari bahasa Inggris 'hoax' dalam bahasa Indonesiakan dipadankan dengankata hoaks. Hoaks merupakan informasi palu yang disampaikan melalui tuturan langsung maupun melalui media sosial. 6

Hoaks merupakan sebagai rangkaian informasi yang memang sengaja disesatkan, namun "dijual” sebagai kebenaran. ${ }^{7}$ Hoaks merupakan berita benar yang sengaja dibuat dan disebarkan untuk menyamarkan serta menutupi kebenaran atas peristiwa atau kasus tertentu. Adapun bentuk

${ }^{6} J u l i s w a r a$, V. (2017). Mengembangkan Model Literasi Media yang Berkebhinnekaan dalam Menganalisis Informasi Berita Palsu (Hoax) di Media Sosial. Jurnal Pemikiran Sosiologi, $4(2), 142-164$

${ }^{7}$ Silverman, Craig. Journalism: A Tow/Knight Report."Lies, Damn Lies, and Viral Content". Columbia Journalism Review (dalam bahasa Inggris), 2015.

Lokakarya Literasi Digital Sebagai Upaya Pemilahan Berita Hoaks Di Desa Menjing, Kecamatan Jenawi, Kabupaten Karanganyar Markhamah, Atiqa Sabardila, Tri Santoso, Wipit Sapitri, Safrudin Athfalusholeh 
hoaks. dibagi menjadi beberapa hal. 8

a. Prinsip yang bertentangan (offence principle)

b. Ide palsu (false idea)

c. Manipulasi media (media manupulation)

d. Melawan netralitas moral (gaints moral neutrality)

e. Keseimbangan (balancing)

f. Objektivitas (objectivity)

Dampak negatif dari adanya media sosial ialah melahirkan maraknya berita hoaks yang berkembang pesat. Setiap individu berkeinginan terlihat eksis dikenal sebagai sumber berita. Mereka dengan gegap menyebarkan (share) berita tanpa meneliti (tabayun) terlebih dahulu atas isi berita, sehingga mereka seringkali terjebak membagikan berita bohong.

Penyebaran hoaks yang begitu masif seringkali membius nalar publik untuk bersikap kritis. Adapun proses penyebaran berita bohong menggunakan pendekatan social engineering. Pendekatan ini merupakan pendekatan yang memanipulasi psikologis dari orang yang menguak atau melakukan aksi suatu informasi berita.

Social engineering biasanya dilakukan menggunakan perangkat media sosial yag terdapat pada gawai yang tersambung dengan perangkat internet. Adapun strategi pada pendekat ini biasanya dengan menggunakan judul dan foto yang fenomenal, akun-akun dengan nama samaran serta foto-foto perempuan cantik atau profil pria yang meyakinkan di media sosial. Tentu hal ini akan membuat orang yang membacanya percaya tanpa harus membuktikan kebenarannya (post truth).

Mereka para penyebar hoaks (misalnya Saracen) lebih teliti dan kreatif dibandingkan dengan warga internet (netizen). Memperhatikan aspek psikologis dan emosional. Hoaks yang semacam ini tentu mengabaikan nalar sehat dan jauh dari etika. Dalam Islam persoalan komunikasi menerima

${ }^{8}$ Almagor, Raphael Cohen. (2013). Freedom of Expression V. Journal of Mass Media Ethics 28 (1): 42-56

Lokakarya Literasi Digital Sebagai Upaya Pemilahan Berita Hoaks Di Desa Menjing, Kecamatan Jenawi, Kabupaten Karanganyar

Markhamah, Atiqa Sabardila, Tri Santoso, Wipit Sapitri, Safrudin Athfalusholeh 
informasi atau berita telah diatur dalam kitab suci alquran surat Al Hujarat ayat 6. Ayat di bawah ini jelas Allah memeritahkan kepada setiap orang untuk meneliti informasi atau berita terlebih dahulu sebelum disebarkan.

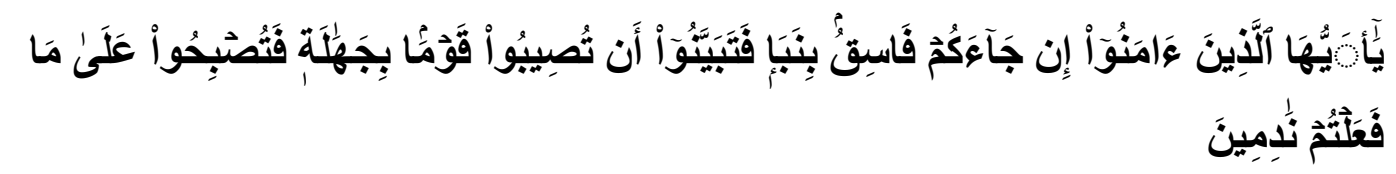

Artinya: Hai orang-orang yang beriman, jika datang kepadamu orang fasik membawa suatu berita, Maka periksalah dengan teliti agar kamu tidak menimpakan suatu musibah kepada suatu kaum tanpa mengetahui keadaannya yang menyebabkan kamu menyesal atas perbuatanmu itu.

Ada beberapa karakteristik suatu berita dapat dikatakan hoaks atau tidak. Di bawah ini merupakan karakteristik suatu berita dikatakan hoaks atau tidak. Beberapa ciri di bawah ini merupakan hasil penelitian dari Kompas sebagai berikut.

\section{a. Judul yang Provokatif}

Judul merupakan intisari berita. Walaupun bentuknya singkat isi berita dapat diketahui melalui judul. Judul dibuat untuk menarik mata pembaca (eye catching), seringkali pada judul ditambahkan gambar untuk mencapai tujuan tersebut. Dengan cara tersebut pembaca akan tergiring untuk menyimpulkan isi berita atau informasi sebelum membaca keseluruhan berita (jump to conclution). Judul-judul berita hoaks mengandung bahasabahasa yang provokatif sebagaimana yang dicontohkan di bawah ini.

Lokakarya Literasi Digital Sebagai Upaya Pemilahan Berita Hoaks Di Desa Menjing, 


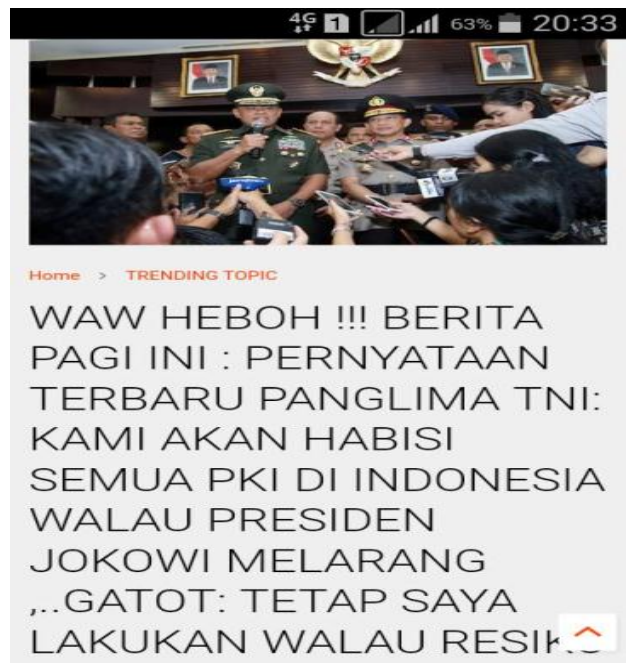

Gambar 2. Hoaks Mengenai Isu PKI (Sumber: Dokumentasi, 2018)

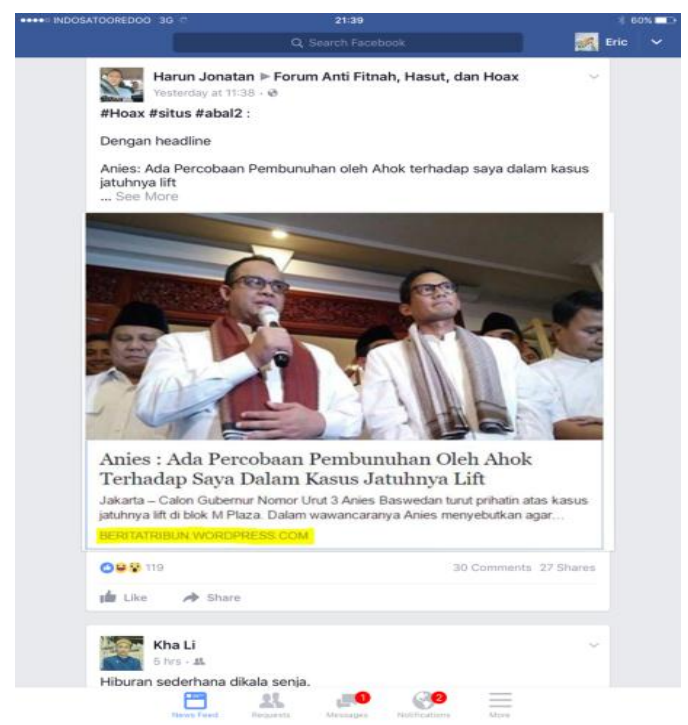

Gambar 3. Hoaks Percobaan Pembuhuhan (Sumber: Dokumentasi, 2018)

Judul berita pada gambar nomor 1 dan 2 besifat provokatif. Pada gambar nomor 1 kalimat provokatif ditandai dengan penggunaan diksi Waw Heboh !! ... Kami Akan Habisi Semua PKI Di Indonesia Walau Presiden Jokowi Melarang. Selain ditandai dengan kalimat yang provokatif juga ditandai dengan adanya penggunaan huruf kapital yang tidak sebagaimana mestinya. Pada gambar nomor 2 judul bersifat provokatif dengan cara melakukan tuduhan atau fitnah pada hal yang sebenarnya tidak dilakukan.

Lokakarya Literasi Digital Sebagai Upaya Pemilahan Berita Hoaks Di Desa Menjing, Kecamatan Jenawi, Kabupaten Karanganyar Markhamah, Atiqa Sabardila, Tri Santoso, Wipit Sapitri, Safrudin Athfalusholeh 
b. Pungtasi yang Berlebihan

Para penyaji berita tentu dibekali dengan penguasaan ejaan yang mendukung. Hal ini untuk menghindarkan kesalahan penulisan pada teks berita. Karakteristik kedua mengenai berita hoaks dapat dilihat dari pungtasi atau tanda baca yang belebihan.

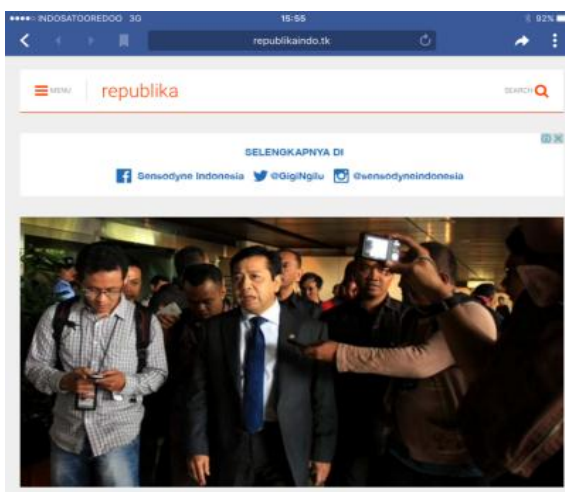

BERITA TERHEBOH MALAM INI...!! Setya Novanto; Jika Ahok Gagal Jadi Gubernur Ahok Akan Kami Angkat Menjadi Ketua KPK..SHARE.

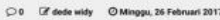

Gambar 4. Hoaks Ditandai dengan Pungtasi Berlebihan (Sumber: Dokumentasi, 2018)

Berita pada Gambar 4 di atas merupakan berita hoaks. Selain tidak masuk akal juga ditandai dengan adanya pungtasi titik dan tanda seru yang berlebihan.

\section{c. Kata yang Berunsur Imperatif}

Berita bohong dapat diindikasikan dengan kalimat yang ditandai dengan kata imperatif baik larangan maupun suruhan. Kaa imperatif yang sering dipakai misalnya waw, heboh, share, bagikan, kirimkan, sebarkan, viralkan dan lain-lain. 


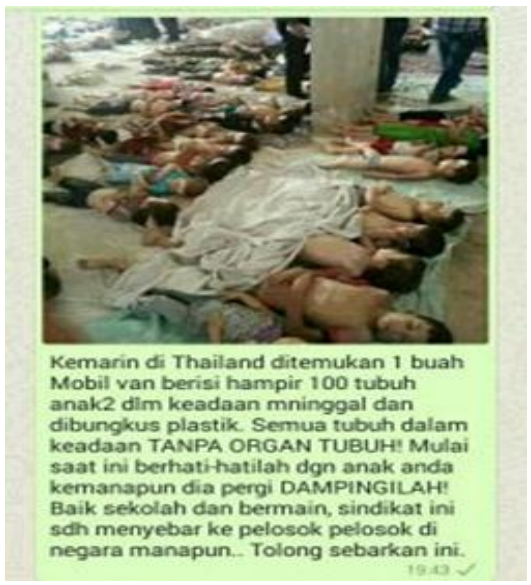

Gambar 5. Hoaks yang Ditandai dengan Kata Imperatif (Sumber: Dokumentasi, 2018)

Berita di atas jelas kebohongannya. Foto yang dipasang merupakan foto korban bencana alam akan tetapi narasi berita diubah menjadi korban mutilasi dan perdagangan organ. Selain ditandai dengan gamba yang tidak sesuai, hoaks pada berita di atas ditandai dengan penggunakan kata imperatif yang meragukan ... tolong sebarkan ini.

\section{d. Bahasa Nirbaku}

Bahasa yang digunakan pada berita bohong biasanya berupa bahasa yang tidak baku sebagaimana yang dicontohkan bawah ini.

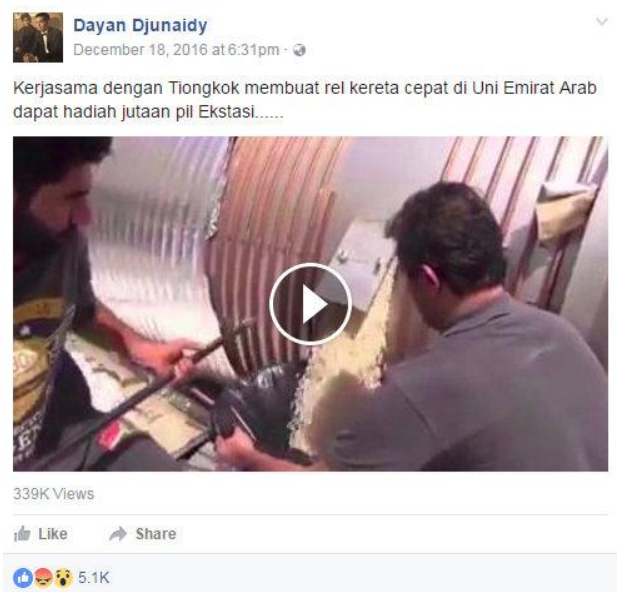

Gambar 6. Hoaks dengan Bahasa Nirbaku (Sumber: Dokumentasi, 2018)

Lokakarya Literasi Digital Sebagai Upaya Pemilahan Berita Hoaks Di Desa Menjing, Kecamatan Jenawi, Kabupaten Karanganyar 
Bahasa pada narasi di atas tidak baku dan terkesan membingungkan bagi siapa saja yang membacanya. Tentu jika dikaitkan dengan berita sesungguhnya tidak masuk akal, tidak mungkin kerja sama antarnegara dengan imbali obat-obatan terlarang (pil ekstasi). Kalimat pada contoh narasi di atas jika dilihat dari struktur bahasanya tidak tergolong dalam kaimat bahasa Indonesia. Subjek yang menjadi hal pokok dalam kalimat tidak ada dalam narasi tersebut.

e. Bahasa yang Mengandung Sarkasme

Sarkasme merupakan bahasa yang kasar dan tidak santun dalam istilah komunikasi. Bahasa sarkasme dihindari dalam dunia jurnalistik karena dirasa dapat menyakiti perasaan orang lain. Di bawah ini merupakan comtoh dari berita hoaks yang menggunakan bahasa kasar.

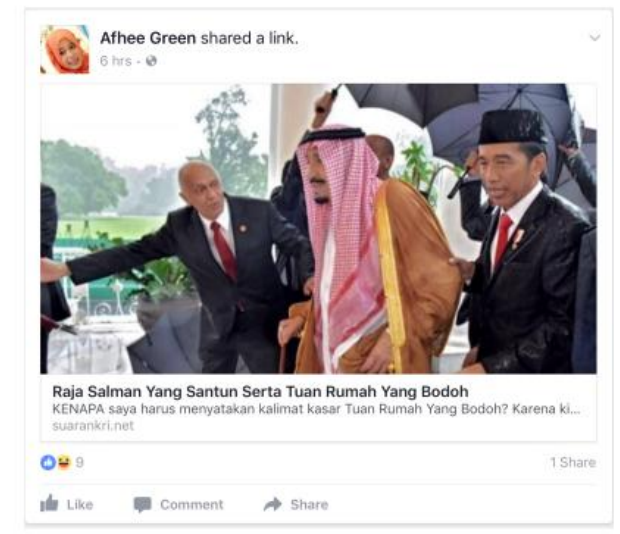

Gambar 7. Hoaks dengan Bahasa yang Mengandung Sarkasme (Sumber: Dokumentasi, 2018)

Secara etika jurnalistik penggunakan kata tuan rumah yang bodoh pada data di atas tidak pantas digunakan. Berita di atas tergolong berita hoaks yang tidak bisa dipertanggungjawabkan kebenarannya.

\section{Tahap Kedua: Sosialisasi Menulis Kreatif di Media Sosial}

Menulis bukan pekerjaan sulit, dibutuhkan kemauan untuk memulai menulis. Ketika dibenak seseorang ada sebuah gagasan, saat itulah harus segera dituangkan dalam tulisan. Menunda keinginan untuk menulis 
merupakan salah satu hambatan besar dalam menulis. Selain ide yang berkurang, semangat untuk menulis akan mengalami pengufangan, bahkan akan hilang seiring dengan kesibukan. Maka ketika ada ide untuk menulis, segera dituangkan dalam bentuk media komunikasi internal yang nantinya informasi itu diketahui orang banyak.

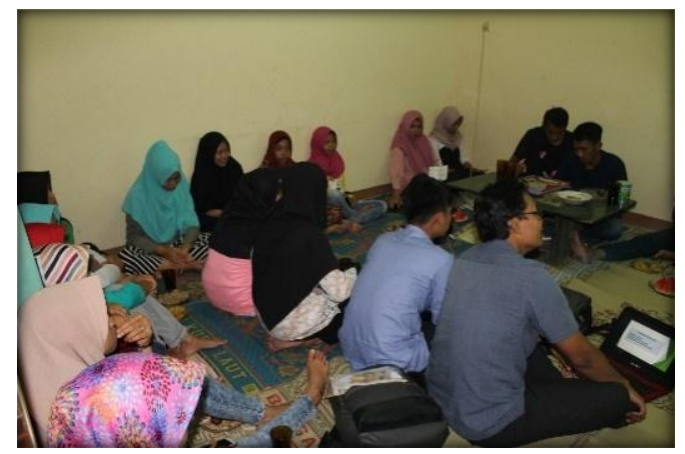

Gambar 8. Penyampaian Materi Sosialisasi Menulis Kreatif di Media Sosial (Sumber: Dokumentasi, 2018)

Agar menulis terlihat mudah dan indah ketika di baca. Biasanya berawal munculnya ide dari seseorang, yang kemudian dituangkan lewat tulisan. Dari tulisan yang telah ada, penulis mengulagi untuk membaca dan memperbaiki diksi agar terlihat estetik. Media pembelajaran adalah bahan, alat, atau teknik yang digunakan dalam kegiatan belajar mengajar dengan maksud agar proses interaksi komunikasi edukasi antara guru dan siswa dapat berlangsung secara tepat guna dan berdaya guna. ${ }^{9}$ Media pembelajaran mempunyai kegunaan sebagai berikut: 1) memperjeas penyajian pesan agar tidak terlalu bersifat verbalistis (dalam bentuk kata-kata tertuis atau lisan belaka). 2) mengatasi ketebatasan ruang, waktu, dan daya indera. 3) dengan menggunakan media pendidikan secara tepat dan bervariasi dapat diatasi sikap pasif anak didik. ${ }^{10}$

Pertama, praktik terlebih dahulu dan teori belakangan, artinya dalam

${ }^{9}$ Lestari, Laila Tri. Kemampuan Menulis Puisi dengan Media Sosial Beetalk Siswa Kelas VIII SMPN 2 Paciran Kabupaten Lamonga. Jurnal Bastra, 4(1):11-18, hal 12, 2017.

10 Sadiman. 2002. Media Pendidikan: Pengertian, Pengembangan, dan Pemanfaatannya. Jakarta : PT Raja Grafindo Persada. Hal 16. 2002.

Lokakarya Literasi Digital Sebagai Upaya Pemilahan Berita Hoaks Di Desa Menjing, Kecamatan Jenawi, Kabupaten Karanganyar Markhamah, Atiqa Sabardila, Tri Santoso, Wipit Sapitri, Safrudin Athfalusholeh 
kegiatan menulis tidak harus dimulai dengan pemahaman kaidah-kaidah menulis. Akan tetapi, sebaiknya siswa diberi kesempatan untuk menulis dan kaidah dapat disampaikan dalam proses. Kedua, menulis sambil "bercanda", artinya menulis harus dilaksanakan dalam suasana yang menyenangkan dan tidak membuat siswa tertekan. Ketiga, kegiatan menulis memerlukan umpan balik, artinya agar kemampuan menulis siswa meningkat, maka dosen rumpun Bahasa Indonesia sebaiknya memeriksa tulisan siswa dan memberikan umpan balik bagian-bagian mana yang masih harus diperbaiki.

\section{Tahap Ketiga: Sosialisasi Santun Bermedia Sosial}

Bagi banyak orang, online communication mempermudah terbentuknya hubungan interpersonal yang dekat, karena melalui komunikasi secara online, tiap individu yang terlibat cenderung lebih berani mengungkapkan pendapatnya, dan membuka dirinya untuk lebih dikenal orang lain. Oleh karena itu, kita ketika ber-Sosial Media hendaknya kita mengenal Etika dan Sopan Santun sehingga kita tidak terjebak dalam hiruk pikuk komentarkomentar yang bisa membawa kita berhadapan hukum. Ketika kita bersosia media kita harus mengetahui prinsip kesantunan (politeness principle) berkenaan dengan aturan tentang hal-hal yang bersifat sosial, estetis, dan moral.

Seorang penutur harus berhati-hati dalam memilih bahasa pada suatu peristiwa tutur. Sekurang-kurangnya ia harus memperhatikan dua hal, yaitu status sosial (dimensi vertikal) dan keakraban (dimensi horisontal) mintra tutur sebab ketidaktepatan pemilihan bahasa penutur terhadap mitra tutur akan menimbulkan kurang nyamannya komunikasi atau komunikasi menjadi tidak lancar. Tanpa disadari terkadang dari beberapa komentar/curhat yang ada di sosmed kerap terjadi hal-hal yang tidak diinginkan yaitu menyinggung perasaan orang lain. 


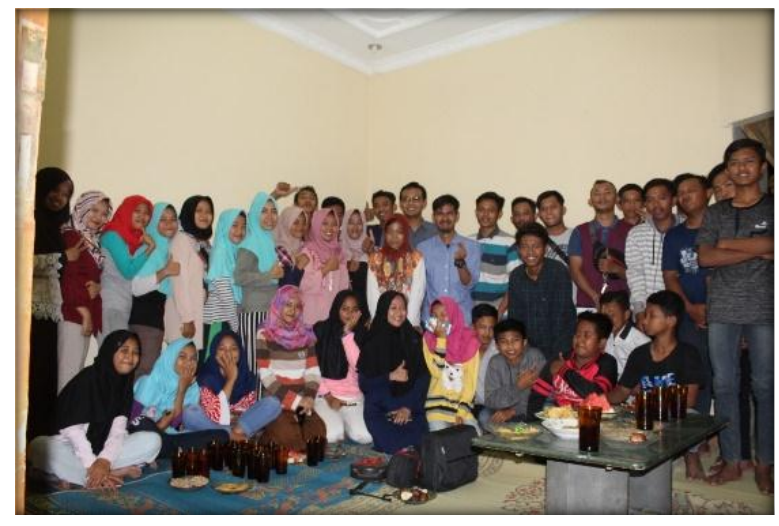

Gambar 9. Peserta dan Pemateri Seuasai Kegiatan (Sumber: Dokumentasi, 2018)

Hal tersebut akan dikenakan sangsi hukum berdasar pada UndangUndang Republik Indonesia nomor 11 tahun 2008 tentang Informasi dan Transaksi Elektronik (UU ITE). Pasal 27 ayat 3 UU ITE, yang berbunyi “ melarang setiap orang dengan sengaja dan tanpa hak mendistribusikan dan/atau mentransmisikan dan/atau membuat dapat diaksesnya Informasi elektronik dan/atau Dokumen Elektronik yang memiliki muatan penghinaan dan/atau pencemaran nama baik."

Suatu tuturan akan terasa santun apabila, a) menjaga suasana perasaan lawan tutur sehingga dia berkenan bertutur dengan kita; b) mempertemukan perasaan kita (penutur) dengan perasaan lawan tutur sehingga isi tuturan sama-sama dikehendaki karena sama-sama diinginkan; c) menjaga agar tuturan dapat diterima oleh lawan tutur karena dia sedang berkenan di hati; d) menjaga agar dalam tuturan terlihat ketidakmampuan penutur dihadapan lawan tutur; e) menjaga agar dalam tuturan selalu terlihat posisi lawan tutur selalu berada pada posisi yang lebih tinggi, dan; f) menjaga agar dalam tuturan selalu terlihat bahwa apa yang dikatakan kepada lawan tutur juga dirasakan oleh penutur. ${ }^{11}$

11 Pranowo. 2012. Berbahasa Secara Santun. Yogyakarta: PustakaPelajar, 103-104, 2012

Lokakarya Literasi Digital Sebagai Upaya Pemilahan Berita Hoaks Di Desa Menjing, 


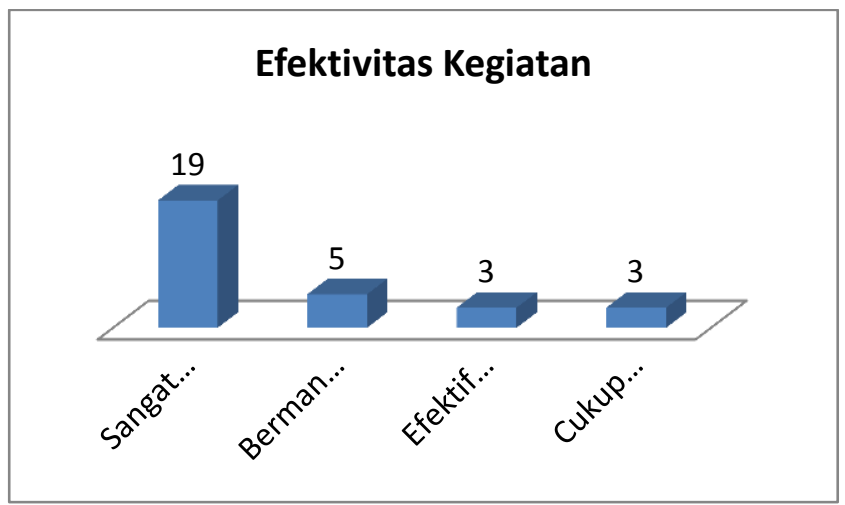

Gambar 10. Efektivitas Kegiatan (Sumber: Data diolah, 2018)

Berdasarkan hasil evaluasi kegiatan sebagaimana yang ditampilkan pada gambar di atas kegiatan PKM ini dapat dikatakan sebagai kegiatan yang efektif. Dari 30 peserta yang ada 29 orang menyatakan bahwa kegiatan ini berjalan dengan efektif. 5 orang menyatakan kegiatan ini bermanfaat, 3 orang menyatakan efektif dan efisien, dan 3 orang menyatakan cukup efektif.

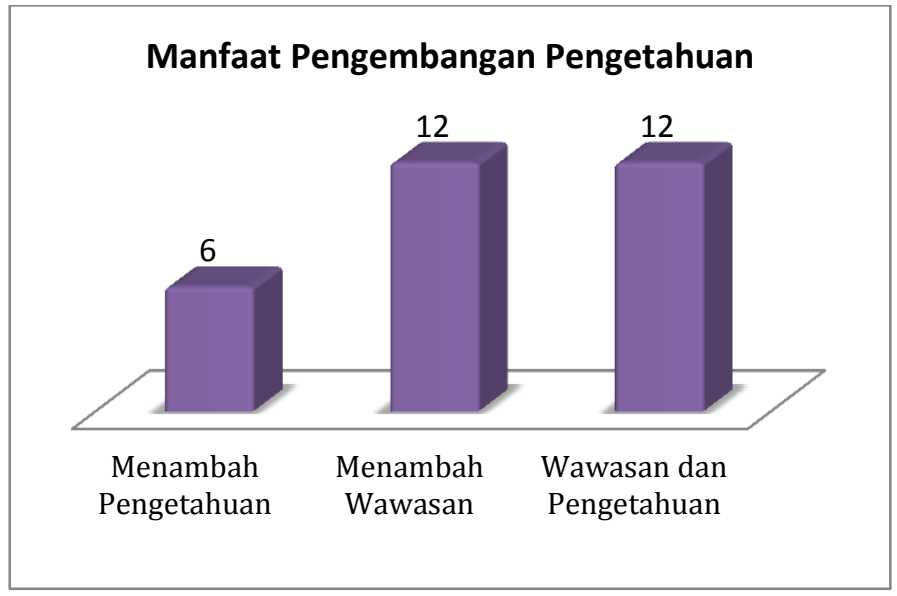

Gambar 11. Manfaat Pengembangan Pengetahuan (Sumber: Data diolah, 2018)

Ada beberapa manfaat yang didapat dari kegiatan pengabdian ini. Berdasarkan 30 orang yang mengikuti kegiatan ini 6 menyatakan menambah pengetahuan, 12 orang menyatakan menambah wawasan, dan 12 orang menyatakan menambah wawasan serta pegetahuan pengetahuan. 


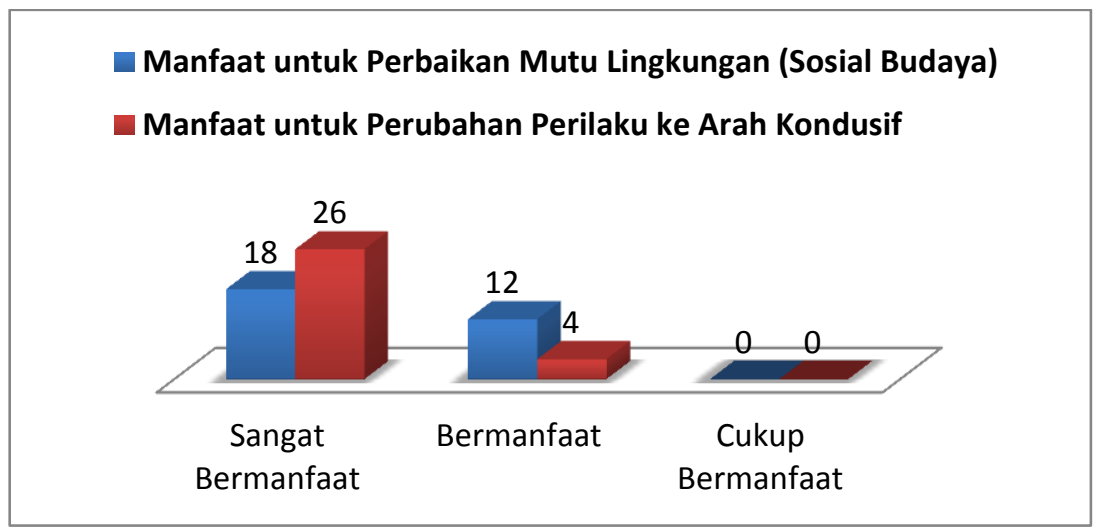

Gambar 12. Manfaat untuk Perbaikan Mutu Lingkungan (Sosial Budaya) dan

Perubahan Perilaku ke Arah Kondusif (Sumber: Data diolah, 2018)

Manfaat dari kegiatan ini untuk perbaikan mutu lingkungan (sosial budaya) 18 menyatakan sangat bermanfaat, 12 orang menanyatakan bermanfaat, dan tidak ada yang memilih cukup bermanfaat. Dari kegiatan ini mereka menyatakan bahwa PKM dapat memangkas peredaran berita hoaks, baik dalam upaya pencegahan maupun pemberantasan. Adapun manfaat untuk perubahan perilaku ke arah kondusif 26 menyatakan sangat bermanfaat, 4 orang menanyatakan bermanfaat, dan tidak ada yang memilih cukup bermanfaat. Manfaat tersebut peserta menjadi tercerahkan dan menjadi selektif dalam menyebarkan informasi (berita).

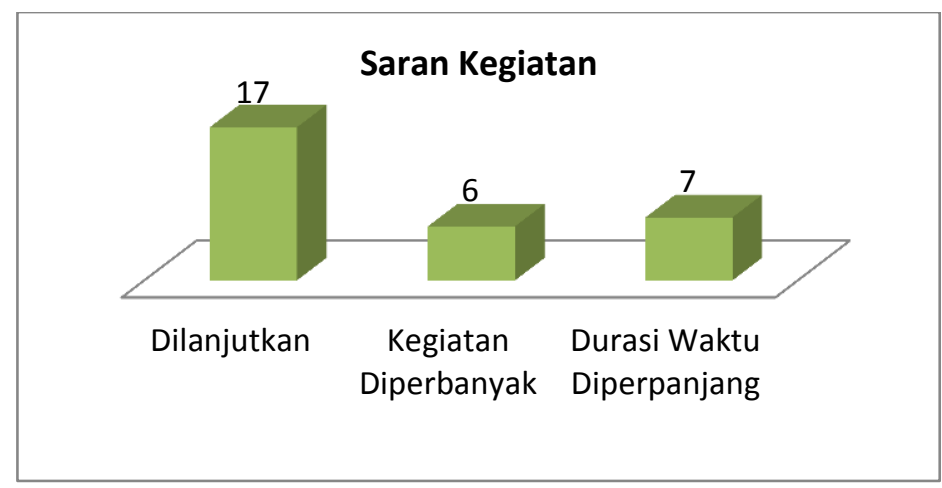

Gambar 12. Saran Kegiatan (Sumber: Data diolah, 2018)

Kegiatan masyarakat ini penting dilaksanakan sebagai wujud pengabdian kepada masyarakat. Selain itu guna memangkas peredaran berita

Lokakarya Literasi Digital Sebagai Upaya Pemilahan Berita Hoaks Di Desa Menjing, 
hoaks. Dari hasil analisis kuensioner yang ada kegiatan ini berjalan dengan efektif. Adapun manfaat yang didapat dari kegiatan ini menurut peserta dapat menambah pengetahuan, wawasan dalam hal bermedia sosial, baik dari kesantunan maupun tata cara menulis berita. Dari hasil analisis dan evaluasi kegiatan peserta yang hadir mengharapkan adanya keberlanjutan 17 orang, 6 orang menyatakan kegiatan diperbanyak bukan hanya sekedar menyampaikan makalah, 3 orang menyarankan untuk durasi waktu diperpanjang. Artinya materi yang disampaikan dapat diterima dengan baik.

\section{Simpulan}

Kegiatan pengabdian kepada masyarakat ini secara garis bersar dapat dikatakan sebagai kegiatan yang sukses. Hal ini dilihat dari indikator banyaknya peserta yang hadir dan didasarkan pada angket yang terisi bahwa mereka mengingikan acara ini diselenggarakan kembali. Adapun saran bagi pihak-pihak yang terlibat dapat mengaplikasikan materi yang disampaikan bahwa ketika bermedia sosial harus memperhatikan aspek-aspek kosopansantunan.

\section{Daftar Referensi}

Almagor, Raphael Cohen. Freedom of Expression V. Journal of Mass Media Ethics 28 (1): 42-56, 2013.

Hancock, J. T. Digital Deception. Oxford Handbook Of Internet Psychology, 289301, 2007.

Juliswara, V. Mengembangkan Model Literasi Media yang Berkebhinnekaan dalam Menganalisis Informasi Berita Palsu (Hoax) di Media Sosial. Jurnal Pemikiran Sosiologi, 4(2), 142-164., 2017.

Keyes, R. The Post-Truth Era: Dishonesty And Deception In Contemporary life. Macmillan, 2004.

Kompas. Cara Cerdas Mencegah Penyebaran Hoax di Media Sosial. https://nasional.kompas.com/read/2017/11/07/08020091/caracerdas-mencegah-penyebaran-hoax-di-media-sosial, 2017.

Lokakarya Literasi Digital Sebagai Upaya Pemilahan Berita Hoaks Di Desa Menjing, 
Lestari, Laila Tri. "Kemampuan Menulis Puisi dengan Media Sosial Beetalk Siswa Kelas VIII SMPN 2 Paciran Kabupaten Lamongan”. Juenal Bastra, 4(1):11-18. Diakses pada 6 Oktober 2018. http://www.journalbastra.org, 2017

Pranowo. Berbahasa Secara Santun. Yogyakarta: PustakaPelajar, 2012.

Sadiman. Media Pendidikan: Pengertian, Pengembangan, dan Pemanfaatannya. Jakarta : PT Raja Grafindo Persada, 2002.

Santosa, P. Materi dan pembelajaran bahasa Indonesia SD. Jakarta: Universitas Terbuka, 2004.

Silverman, Craig. Journalism: A Tow/Knight Report."Lies, Damn Lies, and Viral Content". Columbia Journalism Review (dalam bahasa Inggris) (2015). Diakses tanggal 10-11-2018.

Tania, L., Marindra, G., Melissa, M., Alviyani, V., Risty, I., \& Risalina, R. (2018). Anti Hoax Campaign: Research Based. Manasa, 6(2), 116-126.

Undang-Undang Republik Indonesia nomor 11 tahun 2008 tentang Informasi dan Transaksi Elektronik (UU ITE). 